\title{
Educational Approches in Regional Geography: A Case Study of Southeast Asia
}

\author{
Obrazovni pristupi u regionalnoj geografiji: \\ jugoistočna Azija - studija slučaja
}

Regional geography once featured more importantly in the curriculum of geography at the university level than it does today. In some universities in Slovenia, courses which teach regional geography of Asia are merely electives. This is seen as a weakness since Asia (in the last decade, Southeast Asia in particular) is one of the world's leading economic forces, and the continent with the greatest population. Therefore, geographers should be made more familiar with individual areas of Asia. Our aim was to analyze various course curricula of geography of Southeast Asia in order to gain insights into the internal structure of their education methodology. For this purpose, we analyzed the curricula of geography and 27 learning materials ${ }^{1}$ which deal with Southeast Asia. Another aim was to find out if regional geography of Southeast Asia demands more innovative educational approaches, since many geographers search for employment in that part of the world. We found out that despite people's everyday connection with Southeast Asia through its multiple products and energetic resources ${ }^{2}$, this part of Asia has not been included into the study of regional geography in full integrity.

Key words: : regional geography, Southeast Asia, higher education, Slovenia.
U prošlosti je regionalna geografija imala veću važnost u sveučilišnim nastavnim programima geografije nego danas. Na nekim je slovenskim sveučilištima regionalna geografija Azije samo izborni predmet. To smatramo slabom točkom jer je Azija (a unatrag desetak godina osobito jugoistočna Azija) jedna od vodećih gospodarskih sila i najnastanjeniji kontinent, te bi geografi trebali biti upoznati s pojedinim njezinim regijama. Naš je cilj bio analizirati nastavni program geografije jugoistočne Azije i steći uvid u njegovu strukturu i metodogiju obrazovanja. U tu smo svrhu analizirali nastavne programe geografije i 27 materijala za učenje ${ }^{1}$ geografije jugoistočne Azije. Dodatni nam je cilj bio otkriti zahtijeva li regionalna geografija jugoistočne Azije inovativnije obrazovne pristupe s obzirom na to da mnogo geografa traži posao u tom dijelu svijeta. Otkrili smo da unatoč svakodnevnim vezama s jugoistočnom Azijom zbog mnoštva proizvoda i izvora energije $^{2}$ iz toga dijela svijeta mi i dalje taj dio Azije ne uključujemo posve u poučavanje regionalne geografije.

Ključne riječi: regionalna geografija, jugoistočna Azija, obrazovanje, Slovenija

1 Books, textbooks and magazines about Southeast Asia

1 Knjige, udžbenike, časopise o jugoistočnoj Aziji, skripte i druge vrste materijala za pripremu ispita.

2 Oil, gas and coal

2 Nafta, plin i ugljen. 
HRVATSKI

GEOGRAFSKI

GLASNIK

78/2,101-120 (2016.)

\section{Introduction}

Southeast Asia is a part of a quickly-developing Asia and is becoming a well-known economic unit in the world (Cole, 1996; Pulsipher et al., 2002). Various regional geographic materials about Southeast Asia were analyzed by McAuley and his students in a Pennsylvania (USA) high school thirty years ago (McAuley, 1978). Although the research is older now and many things have certainly changed since then, we are mentioning it because of its specific similarities with our research in regard to contents and textbooks methodologies. Their findings were that in the material regarding Southeast Asia there was an overemphasis on the condition of the countries in times of colonialism, and information about other aspects of history was only presented in general terms. The students thought that textbooks would be much more useful if they were portraying the current conditions of the countries of Southeast Asia. They also all agreed that the textbooks should have a greater emphasis on religions, cultures, and lifestyles of local inhabitants. They felt that contents which presented economic and social causes for the problems that Southeast Asian countries have to face were missing. In their opinion, the textbooks should have at least three maps: a physical map of the entirety of Asia, a topographical map, and a political map of Southeast Asia. The maps should also be harmonized with the context and content of the text. The photographs and illustrations should present more details and help to better understand the entirety of this part of Asia (McAuley, 1978). These findings encouraged us to check the status of today's education regarding Southeast Asia, because Europe is connected to, and, in many respects, dependent upon Asia.

Our students also wanted to know the specific characteristics of individual parts Asia (Kolenc-Kolnik et al., 2002). Textbooks on Southeast Asia in the Slovenian language do not exist; therefore we depend on foreign literature (Blij and Muller, 1997; Hobbs and Salter, 2000). Curricula of the geography of Asia are still largely descriptive and do not provide sufficient competence for students to be able to become involved in Asia-related international projects. Regional geography of Asia is a part of the curriculum at the Department of Geography of the Faculty of Arts at the University of Maribor, the Faculty of Arts of the University of Ljubljana, and the Faculty of Humanities of the University of Primorska. The challenge for the research was to include students into the analysis on the conditions under which they

\section{Uvod}

Jugoistočna Azija dio je brzorazvijajuće Azije i postaje sve poznatija gospodarska cjelina u svjetskim razmjerima (Cole, 1996; Pulsipher i dr., 2002). Regionalnogeografske sadržaje o jugoistočnoj Aziji analizirali su McAuley i njegovi studenti u jednoj srednjoj školi u Pennsylvaniji (SAD) prije gotovo 40 godina (McAuley, 1978). I premda je to istraživanje prilično staro i mnogo se toga promijenilo glede sadržaja i metodologije udžbenika, spominjemo ga zbog određenih sličnosti s našim istraživanjem. Njihova otkrića bila su da se, kad je riječ o jugoistočnoj Aziji, prevelik naglasak stavlja na stanje država u kolonijalnom razdoblju te da su povijesni podaci samo općenito predstavljeni. Studenti su smatrali da bi udžbenici bili mnogo korisniji kad bi upućivali na suvremeno stanje u državama jugoistočne Azije. Usto, svi su se složili da bi se udžbenici mogli više baviti vjerskim uvjerenjima, kulturom i načinom života lokalnoga stanovništva. Studenti su smatrali i da nedostaje sadržaja o suvremenim gospodarskim i društvenim uzrocima problema s kojima se suočavaju države jugoistočne Azije. Prema njihovu bi mišljenju udžbenici trebali sadržavati najmanje tri karte - fizičku kartu cijele Azije, topografsku kartu te političku kartu jugoistočne Azije. K tomu, karte bi trebale biti usklađene s tekstom. Fotografije i ilustracije trebale bi biti detaljnije i pomoći boljem razumijevanju toga dijela Azije (McAuley, 1978). Ta su nas otkrića ohrabrila da provjerimo suvremene uvjete obrazovanja o jugoistočnoj Aziji, posebice sad kad je cijela Europa povezana s Azijom i ovisna o njoj.

Naši studenti također žele poznavati određene značajke regija Azije (Kolenc-Kolnik i dr., 2002). Udžbenici o jugoistočnoj Aziji na slovenskom jeziku ne postoje, pa smo ograničeni na stranu literaturu (de Blij i Müller, 1997; Hobbs i Salter, 2000). Nastavni programi geografije Azije i dalje su uglavnom opisni i ne nude studentima dovoljno stručnoga znanja koje bi im omogućilo uključivanje u međunarodne projekte o Aziji. Regionalna geografija Azije dio je studijskoga programa na Geografskom odjelu Filozofskoga fakulteta Sveučilišta u Mariboru, Filozofskoga fakulteta Sveučilišta u Ljubljani i Fakulteta humanističkih znanosti Sveučilišta na Primorskem. Istraživačima je bio izazov uključiti studente u analizu uvjeta na 
study regional geography of Asia. The research questions were (hypotheses $\mathrm{H} 1$ - H3):

H1: The curricula (of both Slovenian and non-Slovenian Universities) of regional geography of Asia are different in content and scope;

$\mathrm{H} 2$ : The study materials used for regional geography of Southeast Asia are mostly electronic materials using a thematic-problem approach;

H3: The study materials for regional geography of Southeast Asia do not fully take into account and satisfy the demands of students of geography. Therefore, they are appropriate only for general use and are not sufficient for the study of geography at the university level.

\section{Methodology}

For the purposes of this article we analyzed the curricula of geography of Asia (Southeast Asia) at all three Slovenian universities; the University of Maribor (Two-subject teaching second cycle study program Geography, 2013); the University of Ljubljana (Second level Master's teaching-subject study program for Geography (2013); and the University of Primorska (Geography single-subject study program, Regional geography of the world, 2013) ${ }^{3}$. In the research we also we included five universities from the USA (the University Sacramento, the University of Wisconsin, the University of Georgia, the University of South Florida, and the University of San Jose), two universities from Canada (the University of British Columbia and the University of Western Ontario), one university from Singapore (the University of Singapore), and one university from Croatia (the University of Zagreb).

The analysis of the literature was the basis upon which we developed the criteria for the evaluation of study materials from the perspective of students' needs. Furthermore, we developed criteria for the evaluation of the study materials from the perspective of regional-geographic approaches. We analyzed the materials available on the internet, in libraries, and electronic materials discussing Southeast Asia in the empirical part of the research with the help of the previously set criteria. koje nailaze u proučavanju regionalne geografije Azije, a istraživačka su pitanja bila sljedeća (hipoteze $\mathrm{H} 1-\mathrm{H} 3)$ :

H1: Nastavni programi (slovenskih i stranih sveučilišta) regionalne geografije Azije razlikuju se sadržajem i obujmom nastavnih sadržaja.

H2: Materijali za učenje regionalne geografije jugoistočne Azije uglavnom se svode na internetske materijale s tematsko-problemskim pristupom.

H3: Materijali za učenje regionalne geografije jugoistočne Azije ne zadovoljavaju sve potrebe studenata geografije. Dakle, dobri su za opću uporabu, ali ne i za učenje na studiju geografije.

\section{Metodologija}

Za potrebe ovoga članka analizirali smo nastavni program geografije Azije (jugoistočne Azije) na svim trima slovenskim sveučilištima: Sveučilištu u Mariboru (dvopredmetni nastavnički studijski program Geografija, 2013.), Sveučilištu u Ljubljani (diplomski sveučilišni studij Geografija, 2013.) i Sveučilištu na Primorskem (jednopredmetni studijski program Geografija, Regionalna geografija svijeta, 2013.) $)^{3}$. Naše istraživanje također obuhvaća pet američkih sveučilišta (Sveučilište Sacramento, Sveučilište Wisconsin, Sveučilite Georgia, Sveučilište Južna Florida i Sveučilište San Jose), dva kanadska sveučilišta (Sveučilište British Columbia i Sveučilište Western Ontario), jedno singapursko (Sveučilište Singapur) te jedno hrvatsko sveučilište (Sveučilište u Zagrebu).

Analiza literature temelj je na kojem smo razvijali kriterije za vrednovanje materijala za učenje s obzirom na potrebe studenata. K tomu smo razvili kriterij za vrednovanje materijala za učenje s obzirom na zastupljenost regionalnogeografskih pristupa. Također, s pomoću prethodno postavljenih kriterija u empirijskom smo dijelu istraživanja analizirali materijale dostupne na internetu, knjižnicama te elektroničke materijale koji se bave jugoistočnom Azijom.
A. Vovk Korže S. Špoljar

Educational Approches in Regional Geography: A Case Study of Southeast

Asia

Obrazovni pristupi $\mathrm{u}$ regionalnoj geografiji: jugoistočna

Azija - studija slučaja

3 Study program documents are cited in the section Resources and Literature.

3 Dokumenti o studijskim programima navedeni su u poglavlju Izvori i Literatura. 
HRVATSKI

GEOGRAFSKI

GLASNIK

78/2,101-120 (2016.)
Our analysis of the materials regarding Southeast Asia was based on three approaches: a general-geographic approach; a thematic-problem approach; and a combined-regional approach. Tables 1,2 , and 3 present the criteria ${ }^{4}$ used to determine the extent of a material's suitability to certain approaches.
Naša analiza materijala o jugoistočnoj Aziji temelji se na trima pristupima - općegeografskom, tematsko-problemskom te kombiniranom regionalnom pristupu. Tablice 1, 2 i 3 predstavljaju kriterije $^{4}$ za određivanje zastupljenosti određenoga pristupa u materijalima za učenje.

Tab. 1 Criteria used to determine the extent of the presence of the general-geographic approach in materials

Tab. 1. Kriteriji za određivanje zastupljenosti općegeografskoga pristupa u materijalima

\begin{tabular}{|l|c|c|}
\hline \multicolumn{1}{|c|}{ Criteria / Kriteriji } & $\begin{array}{c}\text { The assessment of the presence of the criteria in } \\
\text { selected material / } \\
\text { Procjena prisutnosti kriterija u analiziranim } \\
\text { materijalima }\end{array}$ \\
\hline $\begin{array}{l}\text { Discussion of the region based on natural-geographic and socio- } \\
\text { geographic characteristics / } \\
\text { Razmatranje regije temeljeno na prirodno-geografskim i društveno- } \\
\text { geografskim značajkama }\end{array}$ & No / Ne & Yes / Da \\
\hline $\begin{array}{l}\text { The elements, rather than the countries, are in the foreground / } \\
\text { U prvom planu su elementi, a ne države }\end{array}$ & No / Ne & Yes / Da \\
\hline $\begin{array}{l}\text { Systematic arrangement of the material / } \\
\text { Sustavno uređenje materijala }\end{array}$ & No / Ne & Yes / Da \\
\hline $\begin{array}{l}\text { There are no descriptions of the problems ( it does not go in depth )/ } \\
\text { Nema opisa problema (površna obrada) }\end{array}$ & No / Ne & Yes / Da \\
\hline
\end{tabular}

Source / Izvor: Senegačnik, J., (2005)

Tab. 2 Criteria used to determine the extent of the presence of the thematic-problem approach in the materials Tab. 2. Kriteriji za određivanje zastupljenosti tematsko-problemskoga pristupa u materijalima

\begin{tabular}{|l|c|c|}
\hline \multicolumn{1}{|c|}{ Criteria / Kriteriji } & $\begin{array}{c}\text { The assessment of the presence of the criteria in } \\
\text { selected material / } \\
\text { Procjena prisutnosti kriterija u analiziranim } \\
\text { materijalima }\end{array}$ \\
\hline $\begin{array}{l}\text { Discussion of socio-geographic themes / } \\
\text { Razmatranje društveno-geografske tematike }\end{array}$ & No / Ne & Yes / Da \\
\hline $\begin{array}{l}\text { There is no discussion of individual countries (too general) / } \\
\text { Nema razmatranja po državama }\end{array}$ & No / Ne & Yes / Da \\
\hline $\begin{array}{l}\text { The themes are not connected / } \\
\text { Teme nisu povezane }\end{array}$ & No / Ne \\
\hline $\begin{array}{l}\text { The Problem Approach / } \\
\text { Problemski pristup }\end{array}$ & No / Ne & Yes / Da \\
\hline
\end{tabular}

Source / Izvor: Senegačnik, J., (2005)

\footnotetext{
4 Senegačnik, J. (2005) Geography of Europe in school textbooks of European countries has developed criteria that define the representation of the sustainable dimension in textbooks

4 Senegačnik, J., 2005: Geografija Evrope v šolskih učbenikih evropskih držav, Doktorska disertacija, Univerza v Ljubljani, Filozofska fakulteta, Oddelek za geografijo.
} 
Tab. 3 Criteria used to determine the extent of the presence of the combined-regional approach in the materials

Tab. 3. Kriteriij za određivanje zastupljenosti kombiniranoga regionalnog pristupa u materijalima

\begin{tabular}{|c|c|c|}
\hline Criteria / Kriteriji & \multicolumn{2}{|c|}{$\begin{array}{c}\text { The assessment of the presence of the criteria in } \\
\text { selected material / } \\
\text { Procjena prisutnosti kriterija u analiziranim } \\
\text { materijalima }\end{array}$} \\
\hline $\begin{array}{l}\text { Systematic discussion of the whole region / } \\
\text { Sustavno razmatranje cijeloga područja }\end{array}$ & $\mathrm{No} / \mathrm{Ne}$ & Yes / Da \\
\hline $\begin{array}{l}\text { Discussion of individual countries / } \\
\text { Razmatranje po pojedinačnim državama }\end{array}$ & $\mathrm{No} / \mathrm{Ne}$ & $\mathrm{Yes} / \mathrm{Da}$ \\
\hline $\begin{array}{l}\text { Discussion of the individual themes at the end } \\
\text { (the central problems of the region)/ } \\
\text { Razmatranje pojedinačne teme na kraju } \\
\text { (središnji problemi područja) }\end{array}$ & $\mathrm{No} / \mathrm{Ne}$ & $\mathrm{Yes} / \mathrm{Da}$ \\
\hline The Problem Approach / Problemski pristup & $\mathrm{No} / \mathrm{Ne}$ & Yes / Da \\
\hline
\end{tabular}

Source / Izvor: Senegačnik, J., (2005)

\section{The criteria for the evaluation of materials discussing Southeast Asia from the perspective of the needs of the students}

With the purpose of finding out if the materials discussing Southeast Asia are appropriate for students; we decided to analyze the materials with the needs of students in mind. We formed an evaluation form with criteria representing the needs of students of geography. We formed the criteria independently; however, the criteria were based on our own needs, the wishes of the students of geography, and on the competences written in the syllabus for double-major studies in the first cycle of Bologna study at the Faculty of Arts of the University of Maribor.

With regard to the criteria, we were interested if the chosen materials contained descriptions of current problems (e.g. deforestation, mines, erosion of coral reefs, political issues, tourism, etc.). The curricula of geography at the University of Maribor addresses these issues, as one of the goals for the course of Regional Geography of Asia is that the students become familiar with current events in Asia.

In regard to the criteria looking at whether individual work on the part of the students was encouraged, we were interested if the material included tasks for repetition of subject matter, and how it encourages students to engage in individual work.

\section{Kriterij za procjenu nastavnih materijala} o jugoistočnoj Aziji s obzirom na potrebe studenata

U svrhu provjere jesu li materijali za učenje geografije jugoistočne Azije prikladni za studente odlučili smo analizirati materijale s obzirom na potrebe studenata. Odredili smo obrazac za procjenu s kriterijima koji predstavljaju potrebe studenata geografije. Kriterije smo odredili neovisno, no oni se temelje na našim vlastitim potrebama, željama studenata geografije i kompetencijama navedenim u nastavnom programu preddiplomskoga dvopredmetnog studija Geografija na Filozofskom fakultetu Sveučilišta u Mariboru.

S obzirom na kriterije, zanimalo nas je sadržava li spomenuti materijal opis suvremenih problema (primjerice krčenje šuma, rudnike, eroziju koraljnih grebena, političko stanje, turizam). Ta su pitanja prepoznata u studijskom programu geografije na Sveučilištu u Mariboru jer je jedan od ciljeva kolegija Regionalna geografija Azije da se studente upozna s aktualnim zbivanjima na tom prostoru.

S obzirom na kriterij samostalnoga rada studenata, zanimalo nas je obuhvaćaju li ti materijali za učenje i zadaće za ponavljanje sadržaja te potiču li studente na samostalni rad.
Educational Approches in Regional Geography: A Case Study of Southeast Asia

Obrazovni pristupi u regionalnoj geografiji: jugoistočna

Azija - studija slučaja 
The main research question considering students' environmental awareness attempts to measure the extent to which the material encourages students to think about environmental awareness, in terms of human actions in Southeast Asia. In the curriculum for the course Regional Geography of Asia at the Faculty of Arts of the University of Maribor it is stated that: "A student in the course will gain the following competences: the student will be knowledgeable on the possibilities for environment protection in Asia; and they also become knowledgeable on the causes of the current state of Asia." (Vovk Korža and Hlastan, 2014).

Based on knowledge of the content and competences of the curricula of Asia we developed a survey questionnaire for students of geography. With the survey, we gained some additional suggestions regarding the students' desired kinds of education regarding Asia.

Therefore, we collected 27 learning materials (attachment) deemed appropriate for the research. We have not included encyclopedias, guide books, or other such materials in the analysis because their structure would make it almost impossible to determine their regional-geographic approach. Some electronic materials that were included in the research do not have a date of publication, but we can assume that they were published after the year 1990 following the emergence of information-communication technology.
Glavno istraživačko pitanje glede informiranosti studenta bilo je o tome u kojoj mjeri materijal za učenje potiče studente da promišljaju o utjecaju ljudskoga djelovanja na okoliš u jugoistočnoj Aziji. U nastavnom programu za kolegij Regionalna geografija Azije na Filozofskom fakultetu Sveučilišta u Mariboru stoji: „Student će na kolegiju steći sljedeće kompetencije: usvojiti znanja o mogućnostima zaštite okoliša u Aziji i uzrocima aktualnog stanja u Aziji“" (Vovk Korže i Hlastan, 2014).

$\mathrm{Na}$ temelju poznavanja sadržaja i kompetencija iz nastavnoga programa geografije Azije osmislili smo anketni upitnik za studente geografije. Zahvaljujući tom upitniku otkrili smo dodatne prijedloge o tome kakvu vrstu obrazovanja o Aziji studenti zapravo žele.

Dakle, prikupili smo 27 materijala za učenje prikladnih za istraživanje (u prilogu). Materijala bi bilo i više da nije bilo postavljenih uvjeta. $U$ analizu nismo uključili enciklopedije, vodiče i ostale slične materijale jer struktura tih izvora informacija čini određivanje regionalno-geografskoga pristupa gotovo nemogućim. Pojedini e-materijali uključeni u istraživanje nisu imali naveden datum izdanja, no pretpostavljamo da su objavljeni nakon 1990. godine i pojave informacijsko-komunikacijske tehnologije, odnosno interneta.

Tab. 4 Criteria used to determine the extent of the suitability of the materials for students

Tab. 4. . Kriteriji za određivanje stupnja prikladnosti materijala za studente

\begin{tabular}{|c|c|c|}
\hline Criteria / Kriteriji & \multicolumn{2}{|c|}{$\begin{array}{l}\text { The assessment of the presence of the criteria in } \\
\text { selected material / } \\
\text { Procjena prisutnosti kriterija u analiziranim } \\
\text { materijalima }\end{array}$} \\
\hline $\begin{array}{l}\text { Does the material contain current problems? / } \\
\text { Materijal sadržava aktualne probleme }\end{array}$ & $\mathrm{No} / \mathrm{Ne}$ & Yes / Da \\
\hline $\begin{array}{l}\text { Does the material encourage students to engage in independent work? / } \\
\text { Potiče studente na samostalan rad }\end{array}$ & $\mathrm{No} / \mathrm{Ne}$ & Yes / Da \\
\hline $\begin{array}{l}\text { Does the material strengthen the students' ecological awareness? / } \\
\text { Osnažuje ekološku svijest studenata }\end{array}$ & $\mathrm{No} / \mathrm{Ne}$ & Yes / Da \\
\hline $\begin{array}{l}\text { Does the material encourage critical thinking? / } \\
\text { Potiče kritičko mišljenje studenata }\end{array}$ & $\mathrm{No} / \mathrm{Ne}$ & Yes / Da \\
\hline $\begin{array}{l}\text { Does the material contain recent statistical information? / } \\
\text { Sadržava novije statističke podatke }\end{array}$ & $\mathrm{No} / \mathrm{Ne}$ & Yes / Da \\
\hline $\begin{array}{l}\text { Does the material encourage thinking about the future? / } \\
\text { Potiče razmišljanje o budućnosti }\end{array}$ & $\mathrm{No} / \mathrm{Ne}$ & Yes / Da \\
\hline
\end{tabular}




\section{Regional-geographic approaches in study materials discussing Southeast Asia}

In the research section we analyzed the content of materials discussing Southeast Asia. The purpose of the analysis was to determine which regional-geographic approach was used in the materials. With the analysis, we wanted to find out which approach was the predominant approach, which approach was predominant in regard to the format of the materials and language, and which approach was predominant in regard to the content of the materials.

The analysis started with the collection of materials discussing Southeast Asia in the library and online. At this point, we came across some technical and organizational issues since many foreign textbooks, guidebooks, books, encyclopedias, articles, e-textbooks, and other materials were not free. Another problem was that only some of the materials had a regional-geographic approach. This led us to set some terms, within which we would search for study materials.

With the help of the tables presented above we assessed the presence of the regional-geographic approaches in the selected materials. When the assessed material fulfilled three or four criteria, it meant that the material fit the approach optimally. In cases where the material fulfilled only two criteria, we interpreted it as a partial fit to the approach. The material that did not fulfill any of the criteria did not fit with the approach in question.

For the selected materials, we defined the approach that was the most represented -- this means that if the material was a partial fit for the thematic-problem approach and a perfect fit for the general-geographic approach, we assigned the material to the general-geographic approach category. We had the most problems with determining the approach with materials written in English, because of their unique structure. Such materials are known for their assessment of certain natural-geographic and socio-geographic contents. They also assess some themed contents or current problems, which are shown in the cases of larger countries. We decided to define them as a combined-regional approach, although this approach is known for systematic assessment of the whole region, which does not apply for these materials.

\section{Regionalno-geografski pristupi u nastavnim materijalima o jugoistočnoj Aziji}

U istraživačkom dijelu analizirali smo sadržaj materijala koji obrađuju jugoistočnu Aziju. Svrha je analize bila odrediti koji se regionalno-geografski pristup koristi u materijalima za učenje. Analizom smo htjeli otkriti koji pristup prevladava, koji prevladava glede oblika materijala i jezika te koji prevladava glede sadržaja materijala.

Analiza je započela prikupljanjem materijala o jugoistočnoj Aziji dostupnoga u knjižnici i na internetu. Pritom smo naišli na neke tehničke i organizacijske poteškoće jer pristup većini stranih udžbenika, vodiča, knjiga, enciklopedija, članaka, e-udžbenika i ostalih materijala zahtijeva naknadu. Drugi je problem bio u tome što je samo u nekim materijalima primijenjen regionalno-geografski pristup. To je pak uvjetovalo postavljanje određenih parametara pretraživanja.

$\mathrm{S}$ pomoću kriterija vrednovanja navednih u prethodnim tablicama procijenili smo prisutnost regionalno-geografskih pristupa za svaki odabrani materijal za učenje. Kad je analizirani materijal zadovoljavao tri ili četiri kriterija, savršeno je odgovarao pristupu. U slučajevima kad bi materijal zadovoljavao samo dva kriterija, smatrali smo ga djelomice prikladnim za pristup, dok materijal koji nije zadovoljavao ni jedan od kriterija nije odgovarao odabranom pristupu.

$\mathrm{Za}$ analizirane materijale odredili smo najzastupljeniji pristup. To znači da ako bi materijal djelomice odgovarao tematsko-problemskom pristupu, odnosno u potpunosti općegeografskom pristupu, napisali bismo da materijal ima općegeografski pristup. Najviše problema imali smo s određivanjem pristupa kod materijala na engleskom jeziku zbog njihove jedinstvene strukture. Naime, ti su materijali poznati po zastupljenosti određenih prirodno-geografskih i društveno-geografskih sadržaja. Usto, ti materijali također sadržavaju neke teme i aktualne probleme prezentirane na primjerima većih država. Zato smo te materijale odlučili odrediti kao materijale s kombiniranim regionalnim pristupom unatoč tomu što je taj pristup poznat po sustavnoj procjeni cijele regije, što nije primjenjivo na ove materijale.
Educational Approches in Regional Geography: A Case Study of Southeast

Asia

Obrazovni pristupi u regionalnoj geografiji: jugoistočna

Azija - studija slučaja 
For a more detailed analysis of the materials based on our research questions, we put the results of the evaluated materials into an Excel table. For each selected material we noted the following characteristics:

- author of the material (if there was no author, we wrote the publishing house);

- year of publication;

- type of material or format (electronic, textbook, book, study material, etc.);

- language (Slovenian, English);

- suitability for students (not suitable, partially suitable, or very suitable);

- type of regional-geographic approach used (general-geographic approach, thematic-problem approach, combined-regional approach);

- dominant content (socio-geographic, natural-geographic, equal mixture);

- and the main chapters (contents) of the material.

In the empirical section we presented the results of the research in graph form, where we answered the following research questions:

- Which approach dominates in the selected materials?

- Which approaches dominate based on the type of the material?

- Which approaches dominate based on the language of the material?

- Which contents dominate in the selected materials?

\section{Characteristics of studies of regional geography of Asia}

Our goal of finding the differences among the different study programs of regional geography of Asia at Slovenian universities led us to analyze the curricula of geography of Asia at all three Slovenian universities where geography is taught (the University of Maribor, the University of Ljubljana, and the University of Primorska).

The first difference and the first comparative criterion in the curricula between all three universities was
$\mathrm{K}$ tomu, želeći malo podrobniju analizu materijala temeljenu na našim istraživačkim pitanjima, rezultate ocijenjenih materijala (za vlastite potrebe) unijeli smo u tablicu Excel. Uza svaki od analiziranih materijala naveli smo sljedeće značajke:

- autor materijala (ako ga nema, naveli smo izdavačku kuću)

- godina izdanja

- vrsta materijala (e-materijal, udžbenik, knjiga, priručnik za učenje /skripta/)

- jezik (slovenski, engleski)

- prikladnost za studente (nije prikladan, djelomice prikladan, vrlo prikladan)

- primijenjeni regionalno-geografski pristup (općegeografski pristup, tematsko-problemski pristup, kombinirani regionalni pristup)

- prevladavajući sadržaj (društveno-geografski, prirodno-geografski, isti omjer)

- glavna poglavlja (sadržaj) materijala.

U empirijskom dijelu rada grafički smo predstavili rezultate istraživanja, pri čemu smo odgovorili na sljedeća istraživačka pitanja:

- Koji pristup prevladava u analiziranim materijalima?

- Koji pristup prevladava ovisno o vrsti materijala?

- Koji pristup prevladava ovisno o jeziku materijala?

- Koji sadržaj prevladava u analiziranim materijalima?

\section{Značajke studija regionalne geografije Azije}

$\mathrm{Za}$ potrebe utvrđivanja razlika među različitim studijskim programima regionalne geografije Azije na slovenskim fakultetima analizirali smo nastavne programe kolegija o geografiji Azije na sva tri slovenska sveučilišta na kojima se studira geografija (Sveučilište u Mariboru, Sveučilište u Ljubljani i Sveučilište na Primorskem).

Prva razlika, a time i prvi usporedni kriterij, u studijskim programima između svih triju sveučilišta 
the name of the course. The course where students get to know the characteristics of Asia at the Faculty of Arts of the University of Maribor is called: Regional Geography of Asia. The department for geography at the University of Ljubljana calls their course: Geography of Asia. At University of Primorska they do not have a course that discusses only Asia, rather this theme is a part of a course called: Regional Geography of the World.

The second comparative criterion that helped us perform the analysis of the curricula was the cycle of study that includes the course. The third comparative criterion was the selectiveness of the course. The analysis showed that there are differences among the universities. The students of geography (teaching) at the Faculty of arts of the University of Maribor get familiar with Southeast Asia in their obligatory course Regional Geography of Asia, during the second year of the second cycle of study. At the Faculty of Arts of the University of Ljubljana, students get familiar with regional geography of Asia in an elective course in the first or second cycle of study. At both universities these are stand-alone courses. However, at the University of Primorska, the regional geography of Asia is a part of a course called Regional Geography of the World, which students attend during the first cycle of the study (FF UL, 2013; FHŠ UP, 2013).

We identified some differences regarding the scope of the respective courses and the number of credit points awarded among the universities. At the University of Maribor this course is worth three ECTS points, at the University of Ljubljana four ETCS points, and at the University of Primorska six ECTS points. The fifth criteria regarded the form of work of the course. We found that the courses all dedicate most of their hours to students' individual work, followed by lectures, and the smallest amount of hours is dedicated to seminar work.

The analysis showed that there are not many differences between the courses. All the courses have the following content in common: learning about the socio-geographic and natural-geographic characteristics of Asia.

The criterion regarding the content showed that the content of the courses is similar, as all courses have a focus on the culture and economy of Asia. Some courses also deal with the history of the region, focusing on the colonial and postcolonial pe- bila je u nazivu kolegija. Kolegij na kojem studenti upoznaju značajke Azije na Filozofskom fakultetu Sveučilišta u Mariboru naziva se Regionalna geografija Azije. Geografski odjel Sveučilišta u Ljubljani taj kolegij naziva Geografija Azije, a Sveučilište na Primorskem nema kolegij koji bi se bavio samo Azijom, nego je ta tema dio kolegija Regionalna geografija svijeta.

Drugi usporedni kriterij koji nam je pomogao u analizi studijskih programa bio je ciklus studija na kojemu je kolegij uključen. Treći usporedni kriterij bio je selektivnost kolegija. Analiza je potvrdila da postoje razlike između spomenutih sveučilišta. Studenti nastavničkoga studija geografije na Filozofskom fakultetu Sveučilišta u Mariboru s jugoistočnom se Azijom upoznaju na obveznom kolegiju Regionalna geografija Azije na drugoj godini diplomskoga studija. Na Filozofskom fakultetu Sveučilišta u Ljubljani studenti se s regionalnom geografijom Azije upoznaju na izbornom kolegiju na preddiplomskom ili diplomskom studiju. Na obama sveučilištima (onom u Mariboru i Ljubljani) riječ je o zasebnom kolegiju. Međutim, na Sveučilišstu na Primorskem regionalna geografija Azije dio je kolegija Regionalna geografija svijeta, koji studenti slušaju na preddiplomskom studiju (FF UL, 2013.; FHŠ UP, 2013.).

Uočili smo neke razlike glede obujma nastavnih sadržaja i broja ECTS bodova među sveučilištima. $\mathrm{Na}$ Sveučilištu u Mariboru kolegij vrijedi tri ECTS boda, na Sveučilištu u Ljubljani četiri, a na Sveučilištu Primorska šest ECTS bodova. Peti kriterij obuhvaćao je oblike rada studenata. Otkrili smo da je svim kolegijima zajedničko to da većinu sati posvećuju samostalnom radu studenata, zatim predavanjima, a najmanji broj sati dodijeljen je seminarima.

Analiza je potvrdila da nema velikih razlika među kolegijima. Zajednički je sadržaj svim kolegijima stjecanje znanja o društveno-geografskim i prirodno-geografskim obilježjima Azije.

Kriterij koji se odnosi na sadržaj potvrdio je da je sadržaj kolegija sličan jer su svi kolegiji usredotočeni na kulturu i gospodarstvo Azije. Neki se kolegiji bave i poviješću regije $\mathrm{s}$ fokusom na kolonijalno i poslijekolonijalno razdoblje, a neki su više
Educational Approches in Regional Geography: A Case Study of Southeast

Asia

Obrazovni pristupi u regionalnoj geografiji: jugoistočna

Azija - studija slučaja 
GEOGRAFSKI

GLASNIK

78/2,101-120 (2016.) riods. Some courses are more focused on the future, and they deal with the importance of globalization and sustainable development for Asia.

The comparison of Slovenian curricula and the curricula of non-Slovenian courses showed that courses have different names. While in Slovenia there are courses that discuss the geography of the entirety of Asia, in other countries there are courses that only discuss Southeast Asia. The scope of the courses is similar in Slovenia and in other countries (3-4 ECTS points). The analysis of the content showed that students in both Slovenia and in other countries all learn about the socio-geographic and natural-geographic characteristics of Asia. The differences among the courses can be seen in how emphasis is placed on different content. In non-Slovenian courses the emphasis is on the history of the region and the diversity of ethnic groups. These contents are not included in the Slovenian syllabi.

\section{The representation of regional-geographic approaches in analyzed materials discussing Southeast Asia}

With the purpose of gaining insight into the content and structure of Slovenian and English materials discussing Southeast Asia, we analyzed the materials with criteria for determining the appropriateness of the regional-geographic approaches which are presented in the chapter methodology.

In the materials discussing Southeast Asia the most commonly-used approach was the common-geographic approach (37\%). This means that the materials have systematically-arranged content, divided into socio-geographic and natural-geographic sections. Among the analyzed materials that have common-geographic approaches, we found all of the Slovenian primary school and secondary school textbooks and most of the study materials for students of geography.

Materials discussing Southeast Asia come in diverse formats. Some are printed, for example a book or a textbook, others come in electronic format, and still others come in both printed and electronic formats - where the electronic element has tasks for individual work or is just a book converted to an eBook. usredotočeni na budućnost te se bave važnošću globalizacije za Aziju i održivim razvojem toga kontinenta.

Usporedba slovenskih studijskih programa i programa na sveučilištima u drugim državama otkrila nam je da se kolegiji različito nazivaju. Naime, dok se u Sloveniji kolegiji bave geografijom cijele Azije, na inozemnim se sveučilištima neki kolegiji bave isključivo jugoistočnom Azijom. Vrijednost kolegija u Sloveniji slična je onoj u stranim državama (tri do četiri ECTS boda). Analiza sadržaja otkrila je da studenti u Sloveniji i stranim državama uče o društveno-geografskim i prirodno-geografskim značajkama Azije. Razlika među kolegijima je u obujmu nastavnih sadržaja i naglasku na različit sadržaj. $\mathrm{Na}$ stranim sveučilištama naglasak je na povijesti regije i raznolikosti etničkih skupina, a ti sadržaji nisu dio slovenskih nastavnih programa.

\section{Zastupljenost regionalno-geografskih pristupa $\cup$ analiziranim materijalima o jugoistočnoj Aziji}

Radi stjecanja uvida u sadržaj i strukturu slovenskih i engleskih materijala o jugoistočnoj Aziji, analizirali smo materijale prema kriterijima za određivanje prikladnosti određenoga regionalno-geografskog pristupa predstavljenog u poglavlju Metodologija.

U materijalima za učenje geografije jugoistočne Azije najčešće se upotrebljava općegeografski pristup (37\%), stoga ti materijali imaju sustavno uređen sadržaj podijeljen na društveno-geografski i prirodno-geografski sadržaj. Među analiziranim materijalima s općegeografskim pristupom svi su osnovnoškolski i srednjoškolski udžbenici te većina materijala za učenje namijenjena studentima geografije u Sloveniji.

Materijali za učenje geografije jugoistočne Azije raznovrsnih su oblika. Jedni su u tiskanom obliku, primjerice knjige ili udžbenici, drugi su e-materijali ili e-udžbenici, a treći su pak i u tiskanom i u elektroničkom obliku, s time da e-inačice sadržavaju zadatke za samostalan rad ili je riječ o knjigama pretvorenima u elektronički oblik. 
The materials that were included in the research were $59 \%$ in printed format, $26 \%$ of them were the materials that were in both printed and electronic formats, and only $15 \%$ of them were only in electronic format.

In electronic materials (50\%) and in the materials that were printed (44\%) the most represented approach was the common-geographic approach. The fact that the most represented approach in printed materials was the common-geographic approach is not surprising, as we had already mentioned that this is a frequent approach in Slovenian textbooks. Moreover, it is generally a given that all textbooks for schools come in printed format. For the materials that were in both printed and electronic formats the most represented approach was the thematic-problem approach (57\%).

The analysis included Slovenian and English materials that discuss Southeast Asia. As expected, the analysis showed that there were more materials in English (63\%) than in Slovenian.

There were far more Slovenian materials (80\%) using common-geographic approaches than English materials using the same approach. However, the opposite was true for the thematic-problem approach, which is more characteristically used in English materials (78\%). None of the Slovenian materials that discuss Southeast Asia used a combined-regional approach.

Each of the regional-geographical approaches used a different method of content arrangement. A characteristic of the materials which used the common-geographic approach and the combined-regional approach was that they discussed the natural-geographic and socio-geographic characteristics of the region. The materials using the thematic-problem approach ${ }^{5}$ discussed only socio-geographic topics. Moreover, we were interested in the predominant type of content in the materials discussing Southeast Asia, so for each material we marked the dominant content type.

The dominant type of content in the materials discussing Southeast Asia was socio-geographic (63\%). The second most dominant type of content in materials discussing Southeast Asia was a mix of both natu-
Od materijala obuhvaćenih istraživanjem 59 $\%$ ih je u tiskanom obliku, $26 \%$ u oba oblika (tiskanom i elektroničkom obliku), a samo 15 $\%$ činili su materijali isključivo u elektroničkom obliku.

U e-materijalima (50 \%) i tiskanim materijalima (44 \%) najzastupljeniji je općegeografski pristup. Činjenica da je u tiskanim materijalima najzastupljeniji općegeografski pristup ne iznenađuje s obzirom na to da je, kako smo već spomenuli, taj pristup čest u slovenskim udžbenicima. Štoviše, poznato je da su školski udžbenici u tiskanom obliku. U materijalima koji se pojavljuju u dvama oblicima, tiskanom i elektroničkom, najzastupljeniji je tematsko-problemski pristup (57\%).

Analiza je obuhvaćala materijale za učenje geografije jugoistočne Azije na slovenskom i na stranom (engleskom) jeziku. Kao što se moglo očekivati, potvrđen je veći udio materijala na engleskom (63\%) nego na slovenskom jeziku.

Kad se uzmu u obzir pristupi, mnogo je više materijala s općegeografskim pristupom na slovenskome (80 \%) nego na engleskom jeziku. Međutim, situacija je drukčija glede tematsko-problemskoga pristupa, koji se pokazao svojstvenijim materijalima na engleskome (78\%). Ni jedan od materijala za učenje geografije jugoistočne Azije na slovenskome ne uključuje kombinirani regionalni pristup.

Svaki od regionalno-geografskih pristupa ima drukčiji raspored sadržaja. Značajka materijala $s$ općegeografskim i kombiniranim regionalnim pristupom jest da raspravljaju o prirodno-geografskim i društveno-geografskim obilježjima regije, dok materijali s tematsko-problemskim pristupom raspravljaju samo o društveno-geografskim temama ${ }^{5}$. Usto nas je zanimalo koji sadržaj prevladava u materijalima za učenje geografije jugoistočne Azije te smo za svaki dokument naveli prevladavajući sadržaj.

Tako se pokazalo da u tim materijalima prevladava društveno-geografski sadržaj (63\%), slijede materijali s kombinacijom prirodno-geografskih i
Educational Approches in Regional Geography: A Case Study of Southeast

Asia

Obrazovni pristupi u regionalnoj geografiji: jugoistočna

Azija - studija slučaja

5 Deals with the challenges of the selected area

5 Bave se izazovima odabrane regije. 
GEOGRAFSKI

GLASNIK

78/2,101-120 (2016.) ral-geographic and socio-geographic (26\%). The smallest number of materials had only natural-geographic content $(11 \%)$ as the dominant content type.

\section{Evaluation of study materials discussing Southeast Asia considering their overall usefulness and appropriateness for students of geography}

In order to determine if the selected materials discussing Southeast Asia satisfy the needs of students of geography, we analyzed the materials using criteria which represent the needs of students of geography. The analysis of the study materials, which can be seen in the chapter literature, showed that students of geography have many study materials discussing geography of Asia available online or in the library. However, they have fewer materials focused only on Southeast Asia. Southeast Asia is often a part of courses that deal with general geography of Asia or regional geography of the world. The analysis showed that $37 \%$ of the analyzed materials discussing Southeast Asia are not appropriate for students of geography. The materials that are not appropriate did not fulfil any of the criteria regarding the needs of the students, or fulfilled only one of the criteria. Of the materials, $44 \%$ fulfilled two to four criteria, and were therefore deemed appropriate for students of geography. However, at this point it should be pointed out that these materials are appropriate only for revision of knowledge obtained during high school, and are not appropriate for use as the primary study resource for geography students at the university level. The analysis questions were based on examined materials, and evaluated with the help of table 4 (found earlier in the paper):

- Does the material contain an overview of current problems?

- Does the material encourage students to engage in independent work?

- Does the material strengthen students' ecological awareness?

- Does the material encourage critical thinking?

- Does the material contain the most recent statistical information?

- Does the material encourage thinking about the future?

Figure 1 shows that $37 \%$ of the selected materials were not suitable for geography students. These mate- društveno-geografskih sadržaja (26 \%), dok je najmanji udio materijala (11\%) s prevladavajućim prirodno-geografskim sadržajem.

\section{Vrednovanje materijala za učenje jugoistočne Azzje s obzirom na njhovu korisnost i prikladnost za studente geografije}

Kako bismo odredili zadovoljavaju li odabrani materijali za učenje jugoistočne Azije potrebe studenata geografije, analizirali smo ih korištenjem kriterija koji predstavljaju potrebe studenata geografije. Analiza materijala za učenje (prikazana u poglavlju Literatura) potvrdila je da su studentima geografije dostupni, bilo u knjižnici bilo na internetu, brojni materijali za učenje geografije Azije. Međutim, materijala koji bi se bavili isključivo jugoistočnom Azijom ima manje jer je ta regija nerijetko obrađena kao dio geografije Azije ili regionalne geografije svijeta. Provedena je analiza potvrdila da $37 \%$ analiziranoga materijala o jugoistočnoj Aziji nije prikladno za studente geografije. Neprikladni materijali nisu ispunili postavljene kriterije glede potreba studenata ili su ispunili samo jedan od kriterija. Ukupno uzevši, $44 \%$ ih je ispunilo od dva do četiri kriterija, što ih čini prikladnim za studente geografije. Međutim, valja napomenuti da su ti materijali prikladni samo za revidiranje usvojenoga srednješkolskog znanja o temi te nisu prikladni studentima. Pitanja su određena ovisno o pregledanim materijalima i procijenjena pomoću prije navedene Tablice 4:

- Sadržava li materijal aktualne probleme?

- Potiče li samostalan rad studenata?

- Osnažuje li ekološku svijest studenata?

- Potiče li kritičko mišljenje?

- Sadržava li najnovije statističke podatke?

- Potiče li razmišljanje o budućnosti?

Slika 1 prikazuje da $37 \%$ analiziranih materijala za učenje nije prikladno za studente geografije jer su ti materijali ispunjavali samo jedan ili niti jedan kriterij važan za potrebe studenata. Većina 
rials fulfilled only one or none of the criteria from the perspective of student needs. The majority of the selected materials (as many as $44 \%$ of them) were found to be partially suitable for geography students - which means that these materials fulfilled two to four criteria. But, it should be noted that these materials are not suitable as primary study materials. Only 19\% of the analyzed materials were completely suitable for students of geography, all of which were in English. analiziranih materijala (čak 44 \%) bila je djelomice prikladna za studente geografije, odnosno ispunjavali su od dva do četiri postavljena kriterija. Samo $19 \%$ analiziranih materijala posve je prikladno za studiranje geografije, a svi su bili na engleskom jeziku.

Većina analiziranih materijala sadržava aktualne probleme $(59 \%)$ i potiče na razmišljanje o
Fig. 1 The suitability of the selected materials for geography students

SI. 1. Prikladnost analiziranih materijala za učenje geografije Jugoistočne Azije za studente geografije
A. Vovk Korže S. Špoljar

Educational Approches in Regional Geography: A Case Study of Southeast

Asia

Obrazovni pristupi u regionalnoj geografiji: jugoistočna

Azija - studija slučaja
Most of the analyzed materials contained an overview of current problems (59\%), and encouraged thinking about the future (59\%). Current statistical data was included in the second largest portion of the materials (48\%). Furthermore, $44 \%$ of the materials included tasks for individual work, $37 \%$ of the materials encouraged critical thinking, and $35 \%$ of the materials strengthened student's environmental awareness.

In the research we mentioned that one of the most important competences for geographers is the ability to think critically. The analysis showed that there are only a few materials that encouraged the development of this competence. For this reason, we believe that writers of textbooks should dedicate more attention to encouraging the development of critical thinking abilities. Moreover, university teachers should also encourage students to think critically, to express their opinions and to be able to support those opinions with logical, well-formed arguments.

While analyzing the materials using the criteria with regard to the regional-geographic approach, we wanted to ascertain which approach is the most appropriate for study materials. Unfortunately we were unable to answer that satisfactorily, so we decided instead to com- budućnosti (59\%). Drugi najčešći kriterij koji materijali ispunjavaju jesu noviji statistički podaci (48\%), zadatke za samostalan rad obuhvaća 44 $\%$ materijala, $37 \%$ ih potiče kritičko mišljenje, a 35 \% materijala osnažuje ekološku svijest studenata.

U istraživanju smo spomenuli da je jedna od najvažnijih kompetencija geografa sposobnost kritičkoga mišljenja. Analiza je potvrdila da postoji tek malen broj materijala koji potiču razvoj te kompetencije pa zato smatramo da autori udžbenika tomu trebaju posvetiti više pozornosti. Sveučilišni bi nastavnici trebali poticati studente na kritičko mišljenje, izražavanje svojih stavova i podržavanje logičkih i argumentiranih stavova.

Tijekom analiziranja materijala korištenjem kriterija koji se odnosi na regionalno-geografski pristup, zanimalo nas je koji je pristup najprikladniji za nastavne materijale na studiju. Budući da na to pitanje nismo dobili odgovor, odlučili smo usporediti materijale prema regionalno-geografskim pristupima. Najprikladni- 
GEOGRAFSKI

GLASNIK

78/2,101-120 (2016.) pare the materials according to regional-geographic approaches. The most appropriate materials for students of geography are the ones that use a combined-regional approach (25\%) and the ones that use a thematic-problem approach (22\%). Materials using a common-geographic approach were deemed less appropriate (60\%).

An analysis was made in order to judge the appropriateness of the materials for students in regard to their format. The analysis showed that materials in electronic format $(50 \%)$ are the most appropriate for students of geography. The second most appropriate are the materials that are in both electronic and printed formats (29\%). Among the materials that are in both electronic and printed formats we found none that were inappropriate for geography students.

The research showed that a huge amount of work ought to be done concerning study materials. The optimal study material for geography students which discusses Southeast Asia would be in electronic format, and would use a combined-regional approach, thereby satisfying all the needs of the students. In such a case, students would have all the literature needed for studying Southeast Asia in a single study material.

\section{Is there a need for innovative educational approaches in regional geography?}

Results of the research regarding the names of courses showed that the university courses where students discuss geography of Southeast Asia tend to have different names. Students either get to know Southeast Asia within a course called Geography of Asia or within a course called Geography of East Asia, or they have a separate subject for Southeast Asia. Numerically there are more courses dealing with East Asia, within which Southeast Asia is usually mentioned from the perspective of economic integration. Regarding the scope of the courses, we found out that aforementioned universities all have pretty much the same scope for their courses on geography of Asia, i.e. 3-4 ECTS points per course (Tab. 5).

Regarding the content of the courses in question that deals with Southeast Asia, all courses were found to have an emphasis on the culture and the economy of the continent. Some of the subjects also discussed the history of the region, and had an emphasis on either the colonial and postcolonial eras or a focus on the future and discussing the meaning of globalization and sustainable development for Asia. ji materijali za studente geografije bili su oni s kombiniranim regionalnim pristupom (25\%) i oni s tematsko-problemskim pristupom (22\%). Najmanje prikladnima pokazali su se materijali s općegeografskim pristupom (60\%).

Analizirali smo i prikladnost materijala za studente s obzirom na oblik materijala. Ta je analiza pokazala da su e-materijali (50 \%) najprikladniji za studente geografije. Po prikladnosti ih slijede materijali dostupni i u elektroničkom i u tiskanom obliku (29\%). Među tim dvojnim materijalima nismo pronašli nijedan neprikladan za studente geografije.

Istraživanje je potvrdilo da treba uložiti velik napor glede materijala za učenje. Idealni nastavni materijal za učenje o jugoistočnoj Aziji za studente geografije bio bi u elektroničkom obliku s kombiniranim regionalnim pristupom koji bi zadovoljio sve potrebe studenata. Tako bi studenti svu potrebnu literaturu za izučavanje jugoistočne Azije imali u jednom materijalu za učenje.

\section{Postoji li potreba za inovativnim obrazovnim pristupima u regionalnoj geografiji?}

Rezultati istraživanja o nazivima kolegija pokazali su da se kolegiji na kojima studenti proučavaju geografiju jugoistočne Azije različito nazivaju, što je razlog zašto se neki studenti s jugoistočnom Azijom upoznaju u sklopu kolegija Geografija Azije, a drugi u kolegiju Geografija istočne Azije ili pak imaju zaseban kolegij o jugoistočnoj Aziji. Brojniji su kolegiji koji obuhvaćaju istočnu Aziju i na tim se kolegijima jugoistočna Azija obrađuje iz perspektive gospodarske integracije. Kad se gleda kriterij vrijednosti, kolegiji o geografiji Azije na spomenutim sveučilištima uglavnom imaju istu vrijednost ( 3 do 4 ECTS boda) (tab. 5).

Što se tiče tema, utvrdili smo da je sadržaj kolegija prilično sličan jer je naglasak svih kolegija na kulturi i gospodarstvu Azije. Neki od kolegija također se bave poviješću navedene regije te su usredotočeni ili na kolonijalno i poslijekolonijalno razdoblje ili na budućnost te raspravljaju o utjecaju globalizacije i održivom razvoju Azije. 
Tab. 5 Comparison of the courses on the Geography of Asia at non-Slovenian universities

Tab. 5. Usporedba kolegija o geografiji Azije na stranim sveučilištima

\begin{tabular}{|c|c|c|c|}
\hline $\begin{array}{l}\text { Course name / } \\
\text { Naziv kolegija }\end{array}$ & $\begin{array}{c}\text { University / } \\
\text { Naziv sveučilišta }\end{array}$ & $\begin{array}{l}\text { Credit } \\
\text { points } \\
\text { / Broj } \\
\text { bodova }\end{array}$ & $\begin{array}{l}\text { Course content overview / } \\
\text { Sadržaj kolegija }\end{array}$ \\
\hline $\begin{array}{l}\text { Geography } \\
\text { of East Asia } \\
\text { / Geografija } \\
\text { istočne Azije }\end{array}$ & $\begin{array}{l}\text { University of Sacramento } \\
\text { (USA) / } \\
\text { Sveučilište Sacramento } \\
\text { (SAD) }\end{array}$ & 3 & $\begin{array}{l}\text { The geographic setting of Far East civilizations, settlement, cultures, use } \\
\text { of resources, economy, population, technological development and use of } \\
\text { lands in China, Japan and Korea./ Geografski položaj civilizacija Dale- } \\
\text { koga istoka, naselja, kultura, iskorištavanje resursa, gospodarstvo, nasel- } \\
\text { jenost, tehnološki razvoj i korištenje zemljišta u Kini, Japanu i Koreji. }\end{array}$ \\
\hline $\begin{array}{l}\text { East and South } \\
\text { Asia / } \\
\text { Istočna i južna } \\
\text { Azija }\end{array}$ & $\begin{array}{l}\text { University of San Jose } \\
\text { (USA) / } \\
\text { Sveučilište San Jose } \\
\text { (SAD) }\end{array}$ & 3 & $\begin{array}{l}\text { Environmental, historical, political, and economic geography. An em- } \\
\text { phasis on the comparison and analysis of the economic progress in the } \\
\text { region. / Geografija okoliša (Geoekologija), historijska, politička i ekon- } \\
\text { omska geografija. Naglasak na usporedbi i analizi gospodarskoga razvoja } \\
\text { u regiji. }\end{array}$ \\
\hline $\begin{array}{l}\text { Geography of } \\
\text { Asia / Geografija } \\
\text { Azije }\end{array}$ & $\begin{array}{l}\text { University of South Florida } \\
\text { (USA) / } \\
\text { Sveučilište Južne Floride } \\
\text { (SAD) }\end{array}$ & 4 & $\begin{array}{l}\text { Systematic geographic analysis of the Asian region, with an empha- } \\
\text { sis on its cultural, political, economic, environmental, and physical } \\
\text { diversity. / Sustavna geografska analiza azijske regije s naglaskom } \\
\text { na kulturološku, političku, gospodarsku, ekološku i fizičku raz- } \\
\text { novrsnost. }\end{array}$ \\
\hline $\begin{array}{l}\text { Geography } \\
\text { of East Asia } \\
\text { / Geografija } \\
\text { istočne Azije }\end{array}$ & $\begin{array}{l}\text { University of Georgia } \\
\text { (USA) / } \\
\text { Sveučilište Georgia } \\
\text { (SAD) }\end{array}$ & 3 & $\begin{array}{l}\text { Physical geography, regional development of the countries from Sin- } \\
\text { gapore to Korea, population and migrations, environmental degrada- } \\
\text { tion, agriculture and technological development. / Fizička (prirodna) } \\
\text { geografija, regionalni razvoj država od Singapura do Koreje, naseljenost i } \\
\text { migracije, degradacija okoliša, poljoprivreda i tehnološki razvoj. }\end{array}$ \\
\hline $\begin{array}{l}\text { Sociogeography } \\
\text { of Southeast } \\
\text { Asia / Društvena } \\
\text { geografija jugois- } \\
\text { točne Azije }\end{array}$ & $\begin{array}{l}\text { University of Wisconsin } \\
\text { (USA) / } \\
\text { Sveučilište Wisconsin } \\
\text { (SAD) }\end{array}$ & 3 & $\begin{array}{l}\text { Examination of the countries of Southeast Asia, colonial and } \\
\text { postcolonial eras, ethnic groups and state borders of individual } \\
\text { countries. / Pregled država jugoistočne Azije, kolonijalno i poslije- } \\
\text { kolonijalno razdoblje, etničke skupine i državne granice pojedinih } \\
\text { država. }\end{array}$ \\
\hline $\begin{array}{l}\text { Geography of } \\
\text { Southeast Asia / } \\
\text { Geografija jugo- } \\
\text { istočne Azije }\end{array}$ & $\begin{array}{l}\text { University of British } \\
\text { Columbia (Canada) / } \\
\text { Sveučilište Britanska } \\
\text { Kolumbija (Kanada) }\end{array}$ & 3 & $\begin{array}{l}\text { Critical analysis of the important characteristics of the political, eco- } \\
\text { nomic, and cultural development in the region from pre-colonial times } \\
\text { through present day. / Kritička analiza važnih značajka političkoga, gos- } \\
\text { podarskoga i kulturnog razvoja u regiji od pretkolonijalnoga doba do } \\
\text { danas. }\end{array}$ \\
\hline $\begin{array}{l}\text { Geography } \\
\text { of East and } \\
\text { Southeast Asia } \\
\text { / Geografija } \\
\text { istočne i jugois- } \\
\text { točne Azije } \\
\end{array}$ & $\begin{array}{l}\text { University of West Ontario } \\
\text { (Canada)/ } \\
\text { Sveučilište West Ontario } \\
\text { (Kanada) }\end{array}$ & 3 & $\begin{array}{l}\text { Environment and people, population, urbanization, migrations, agricul- } \\
\text { ture, East Asia as a center of the world, China, Asian tigers, Southeast } \\
\text { Asia: land and sea aspects. / Okoliš i stanovništvo, naseljenost, urban- } \\
\text { izacija, migracije, poljoprivreda, istočna Azija kao središte svijeta, Kina, } \\
\text { azijski tigrovi, jugoistočna Azija: kopneni i morski dio. }\end{array}$ \\
\hline $\begin{array}{l}\text { Southeast Asia / } \\
\text { Jugoistočna Azija }\end{array}$ & $\begin{array}{l}\text { University of Singapore } \\
\text { (Singapore)/ } \\
\text { Sveučilište Singapur } \\
\text { (Singapur) }\end{array}$ & 4 & $\begin{array}{l}\text { Understanding of the regional geography of Southeast Asia through } \\
\text { historical, cultural, social, and political-economic perspectives. Sustain- } \\
\text { able development in the region. / Razumijevanje regionalne geografije } \\
\text { jugoistočne Azije s povijesne, kulturološke i gospodarsko-političke pers- } \\
\text { pektive. Održivi razvoj u regiji. }\end{array}$ \\
\hline $\begin{array}{l}\text { Geography } \\
\text { of East Asia } \\
\text { / Geografija } \\
\text { Istočne Azije }\end{array}$ & $\begin{array}{l}\text { University of Zagreb } \\
\text { (Croatia)/ } \\
\text { Sveučilište u Zagrebu, } \\
\text { Prirodoslovno-matematički } \\
\text { fakultet (Hrvatska) }\end{array}$ & 3 & $\begin{array}{l}\text { Natural-geographic characteristics, population, historical development, } \\
\text { economical characteristics, regional examination of the countries, mod- } \\
\text { ern processes, and globalization of the East Asia. / Prirodno-geografske } \\
\text { značajke, naseljenost, povijesni razvoj, gospodarske značajke, regionalni } \\
\text { pregled država, suvremeni procesi i globalizacija istočne Azije. }\end{array}$ \\
\hline
\end{tabular}

Educational Approches in Regional

Geography: A Case Study of Southeast

Asia

Obrazovni pristupi u regionalnoj geografiji: jugoistočna

Azija - studija slučaja 
The comparison of Slovenian syllabi and their counterparts from other countries has shown that the subjects have different names. In Slovenia there are courses dealing generally with the geography of Asia. Meanwhile, many universities outside of Slovenia have courses which deal with Southeast Asia specifically. Regarding the course content makeup we found that the students always learn about the natural-geographic and socio-geographic aspects of Southeast Asia. The differences between courses are largely found in their focus and emphasis on specific themes. For example, at non-Slovenian universities there is sometimes an emphasis on the history of the region and the diversity of ethnic groups, which is something that typically is not a part of Slovenian courses.

The analysis of the curricula showed that there are not many differences between the curricula in Slovenia and those of non-Slovenian universities ( 3 to 4 ECTS points $\left.{ }^{6}\right)$. Based on the results of this analysis, we can partially confirm hypothesis $\mathrm{H} 1$ that assumed that the curricula for courses dealing with regional geography of Asia were similar in content and scope. The scope of the courses was very similar, however, differences were found in the number of hours spent in class, seminars, and individual work.

The results of the analysis of the materials discussing Southeast Asia rejected hypothesis H2. The hypothesis assumed that the predominant type of material dealing with Southeast Asia was an electronic material using a thematic-problem approach. The analysis showed that in the materials discussing Southeast Asia a variety of different approaches were used, but the most commonly used approach was the common-geographic approach, which happens to be the typical approach of Slovenian textbooks. The analysis also included materials that were in both electronic and printed format. Materials that were in both formats were predominantly non-Slovenian in origin, and typically consisted of printed content and study tasks with questions and exercises in electronic format. Here we also included non-Slovenian books that were in printed format and in PDF format available online.

The analysis of the materials showed that only $19 \%$ were appropriate for students of geography, all of which were in English. This is not a surprising fact since the least
Usporedba slovenskih i nastavnih programa drugih država potvrdila je da se kolegiji različito nazivaju. Slovenski se kolegiji bave geografijom Azije (geografijom cijeloga kontinenta), a druga sveučilišta imaju izdvojene kolegije koji se bave samo jugoistočnom Azijom. Glede sadržaja kolegija, utvrdili smo da studenti uvijek upoznaju prirodno-geografska i društveno-geografska obilježja jugoistočne Azije, a kolegiji se razikuju po obujmu nastavnih sadržaja i glavnim temama. Primjerice, na neslovenskim se sveučilištima katkad stavlja naglasak na povijest regije i raznolikosti etničkih skupina, čime se slovenski kolegiji ne bave.

Provedena analiza nastavnih programa pokazala je da nema bitnih razlika između nastavnoga plana slovenskih i neslovenskih sveučilišta (tri do četiri ECTS boda ${ }^{6}$ ). Na temelju dobivenih rezultata možemo djelomice potvrditi hipotezu H1, koja pretpostavlja da se nastavni program kolegija Regionalna geografija Azije razlikuje sadržajem i obujmom nastavnih sadržaja. Količina nastavnih sadržaja vrlo je slična, a razlike postoje samo u broju sati predavanja, seminara i samostalnoga rada.

Rezultati analize materijala za učenje geografije jugoistočne Azije odbacili su hipotezu H2, koja je pretpostavljala da su prevladavajući nastavni materijali o jugoistočnoj Aziji uglavnom e-materijali s tematsko-problemskim pristupom. Naime, analiza je dokazala da se u nastavnim materijalima o jugoistočnoj Aziji rabe različiti pristupi, no najčešći je općegeografski pristup svojstven slovenskim udžbenicima. Analizom su također obuhvaćeni materijali za učenje obaju oblika, tiskani i elektronički. Ti su materijali uglavnom bili na stranom jeziku, sa sadržajem u tiskanom, a zadacima i vježbama u elektoničkom obliku. U analizu smo također uključili inozemne tiskane knjige dostupne na internetu u PDF obliku.

Analiza nastavnih materijala pokazala je da je samo $19 \%$ svih materijala prikladno za studente geografije, a svi su oni na engleskom jeziku. To

\footnotetext{
6 ECTS is a measure of the range of subjects in Europe. Outside Europe used credits and value of 1 credit point is approximately half the ECTS points.

6 ECTS (Europski sustav prijenosa i prikupljanja bodova) je alat za usporedbu kolegija u Europi. Izvan Europe koristi se bodovni sustav i vrijednost jednog boda približna je polovici ECTS boda.
} 
appropriate materials were the materials using the common-geographic approach, which is typical for Slovenian primary school and secondary school textbooks. Through these findings we were able to confirm hypothesis $\mathrm{H} 3$, which states that the materials discussing Southeast Asia do not fully take into account or satisfy the needs of geography students, and are therefore appropriate only for general use and not for studying geography at the university level.

Some improvements in the quality of study materials are already evident. This can be seen in the non-Slovenian materials discussing Southeast Asia that have geographic content and are in printed format with tasks, exercises, study questions, animations, and descriptions of current problems in electronic format. In the opinion of the authors, these kinds of materials would also be interesting and useful to Slovenian geography students.

\section{Conclusion}

We have analyzed materials while considering the regional-geographic approaches used and the needs of students of geography. The analysis showed that the majority of materials discussing Southeast Asia used a common-geographic approach. However, in the aforementioned materials the thematic-problem approach and the combined-regional approaches are also often found. The research data showed that the combined-regional approach is also the most appropriate approach for students of geography. The combined-regional approach deals first with natural-geographic and socio-geographic characteristics of the region, then with countries in the region, and last it deals with problems in the region. The materials using this approach are the most geographically detailed materials. The respondents evaluated that the most important criteria for the quality of materials is their comprehensibility, accessibility, and that they included current problems. The inclusion of current problems and general accessibility can be easily addressed using modern information technology. This is a priority that should be incorporated in teaching regional geography of Asia. Regional geography of Asia should be based not only on detailed knowledge and analysis of current problems in Asia, but also in discovering its future potential, options for economic integration, and understanding of culture. We rate the inclusion these types of content, along with socio-geographic and natural-geographic characteristics, as highly important. ne iznenađuje ako se ima na umu da su najneprikladniji materijali oni s općegeografskim pristupom, svojstvenim za slovenske osnovnoškolske i srednjoškolske udžbenike. Time smo potvrdili hipotezu H3, koja pretpostavlja da nastavni materijali o jugoistočnoj Aziji ne uzimaju u obzir i ne zadovoljavaju potrebe studenata geografije te su namijenjeni za opću uporabu, a ne studiranje geografije.

Neka poboljšanja u kvaliteti materijala za učenje već su vidljiva, ali ponajprije u inozemnim materijalima o jugoistočnoj Aziji s geografskim sadržajem u tiskanom obliku, a sa zadacima, vježbama, istraživačkim pitanjima, animacijama i opisima aktualnih problema u elektoničkom obliku. Mislimo da bi takvi materijali zacijelo bili zanimljivi i studentima geografije u Sloveniji.

\section{Zaključak}

Nastavne materijale analizirali smo sa stajališta regionalno-geografskog pristupa i potreba studenata geografije, a analiza je potvrdila da u većini materijala za učenje geografije jugoistočne Azije prevladava općegeografski pristup. Međutim, u analiziranim nastavnim materijalima zastupljeni su i tematsko-problemski pristup i kombinirani regionalni pristup. Rezultati istraživanja također su dokazali da je kombinirani regionalni pristup najprikladniji za studente geografije. Naime, kombinirani regionalni pristup ponajprije se bavi prirodno-geografskim i društveno-geografskim značajkama područja ili regije, a tek onda državama regije te, naposljetku, problemima određenoga područja. Materijali s takvim pristupom geografski su najdetaljniji. Ispitanici ocijenjuju da je najvažniji kriterij kvalitete materijala njihova razumljivost, dostupnost i uključenost aktualnih problema. Uključenost aktualnih problema i dostupnost olakšani su korištenjem informacijske tehnologije. Regionalna geografija Azije ne bi se trebala temeljiti samo na detaljnom znanju i analizi aktualnih problema u Aziji nego i na otkrivanju potencijala regije, mogućnostima za gospodarsku integraciju i razumijevanju kulture. Smatramo da je taj sadržaj, zajedno s društveno-geografskim i prirodno-geografskim značajkama, iznimno važan. K
Educational Approches in Regional Geography: A Case Study of Southeast

Asia

Obrazovni pristupi u regionalnoj geografiji: jugoistočna

Azija - studija slučaja 
GLASNIK

78/2,101-120 (2016.)

Note Napomena

Literature

Literatura

Sources

Izvori
Moreover, the knowledge of regional geography of Asia is not only important for future teachers but also for other experts in related fields of study. Teachers and said experts should work together to enable an exchange of knowledge and a better understanding of the conditions for sustainable and socially responsible development that would be based on knowledge of Southeast Asia from environmental, economic, and social points of view.

Professional Terms Editing: Ružica Vuk, PhD, Assistant Professor tomu, poznavanje regionalne geografije Azije nije važno samo za buduće učitelje/nastavnike nego i za ostale stručnjake. Učitelji/nastavnici i ostali stručnjaci trebali bi surađivati na razmjeni znanja i boljega razumijevanja uvjeta za održiv i društveno odgovoran razvoj koji bi se temeljio na znanju o jugoistočnoj Aziji s ekološkoga, gospodarskoga i društvenoga aspekta.

Stručna redaktura: doc. dr. sc. Ružica Vuk
Cole, J., 1996: Geography of the world's major regions: textbook, Routledge, London, New York.

Harm J., de Blij, Muller, J., 1997: Geography: Realms, Regions and Concepts: textbook, J. Wiley \& Sons, New York.

Hobbs, J. J., Salter, C. L., 2000: Essentials of World Regional Geography: textbook., Brooks/Cole Publishing, UK.
Kolenc-Kolnik K., Otič M. Vovk Korže A., 2002: Sodobni svet: Geografija za 7. razred osnowne šole: učbenik [Geography for 7th grade primary school: textbook], Modrijan/Modern World, Ljubljana.

Pulsipher, L. M., Pulsipher, A. A., 2002: World Regional Geography: Global Patterns, Local Lives: textbook, W.H. Freeman and Company, New York.
Senegačnik, J., 2005: Geografija Evrope v šolskih učbenikih evropskih držav [Geography of Europe in school textbooks of European countries], Doktorska disertacija, University of Ljubljana, Faculty of Liberal Arts, Department of Geography.

Vovk Korže, A., Hlastan, A., 2014: Geografski pogled na problematiko vodovja v Aziji: textbook. Univerza v Mariboru, Mednarodni center za ekoremediacije.

San José State University, 2013: East and South Asia, San José State University Catalog, http://info.sjsu.edu/webdbgen/catalog/ courses/GEOG160.html (19. 4. 2014).

University of Maribor, Faculty of Arts, Department of Geography, 2013: FF UM - Two-subject teaching second cycle study program Geography / FF UM - Dvopredmetni pedagoški študijski program druge stopnje Geografija, http://www.ff.uni-mb.si/studenti/studijs$\mathrm{ki}$-programi/druga-stopnja/geografija/dv_ped_druga_geografija.dot (13.3.2014.).

University of Ljubljana, Faculty of Arts, Department of Geography, 2013: FF UL Second level Master's teaching-subject study program Geography / FF UL - Drugostopenjski magistrski pedagoški dvopredmetni študijski program geografija, http://geo.ff.uni-lj. si/2-stopnja-geografija (13.3.2014.).

University of Primorska, Faculty of Humanities, Department of Geography, 2013: FHS UP - Geography singlesubject study program, Regional geography of the world / FHŠ UP - Geografija enopredmetni študijski program, Regionalna geografija sveta, http:// www3.fhs.upr.si/s1/studenti/studij/studij-1-stopnja/geografija/predmetnik_enopredmetnega_studijskega_programa/ (13. 3. 2014.).

Sacramento State University, 2013: Geography of East Asia, Sacramento State University Catalog, Geography, Undergraduate Programs, Regional geography, http://catalog.csus.edu/current/programs/geog.html (19. 4. 2014.).

University of South Florida, College of Art and Science, 2013: Geography of Asia, Undergraduate study, Information for Geography Majors, http://hennarot.forest.usf.edu/main/depts/geosci/ug/geography/ (19. 4. 2014.).

Georgia State University, Department of Geoscience, 2013a: Geography of East Asia, Graduate Geography Courses, http://geosciences.gsu.edu/1638.html (19. 4. 2014.).

University of British Columbia, Department of Geography, 2013: Geography of Southeast Asia, Courses in Geography, http://www. geog.ubc.ca/undergraduate/courses_all.html (19.4.2014.). 
The University of Western Ontario, Department of Geography, 2013: Geography of East and Southeast Asia, http://geography.uwo. ca/undergrad/courses/2040A.pdf (19. 4. 2014.).

University of Zagreb, Faculty of Science, Department of Geography, 2013: Geography of East Asia/Geografija Istočne Azije, http:// www.pmf.unizg.hr/geog/predmet/gia (19. 4. 2014.).

University of Wisconsin-Madison, Department of Geography, 2014: Human Geography of Southeast Asia, http://www.geography. wisc.edu/courses/syllabi/358_spring.pdf (19.4.2001).

National University of Singapore, Department of Geography, 2013: Southeast Asia, Undergraduate Modules, http://www.fas.nus. edu.sg/geog/undergrads/undergrad_modules.html\#tab2-tab (19.4.2014.).

McAuley, J. D., 1978: Evaluation of Textbook Content on Southeast Asia, The Clearing House: A Journal of Educational Strategies, Issues and Ideas 52, 105-106, http://www.tandfonline.com/doi/abs/10.1080/00098655.1978.9958182?journalCode=vtch20\#. UwTwCv15Ps4 (19. 2. 2014.).

\section{Curricula documents/Dokumenti o nastavnom programu}

Filozofska fakulteta v Mariboru, Oddelek za geografijo, 2013: FF UM - Dvopredmetni pedagoški študijski program druge stopnje Geografija, http://www.ff.uni-mb.si/studenti/studijski-programi/druga-stopnja/geografija/dv_ped_druga_geografija.dot (13. 3 . 2014.).

Filozofska fakulteta v Ljubljani, Oddelek za geografijo, 2013: FF UL - Drugostopenjski magistrski pedagoški dvopredmetni študijski program geografija, http://geo.ff.uni-lj.si/2-stopnja-geografija (13.3.2014).

Fakulteta za humanistične študije, Oddelek za geografijo, 2013: FHŠ UP - Geografija enopredmetni študijski program, Regionalna geografija sveta, http://www3.fhs.upr.si/sl/studenti/studij/studij-1-stopnja/geografija/predmetnik_enopredmetnega_studijskega_programa/ (13.3.2014)

Sacramento State University, 2013: Geography of East Asia, 2013, Sacramento State University Catalog: Geography: Undergraduate Programs: Regional geography, http://catalog.csus.edu/current/programs/geog.html (19. 4. 2014).

San José State University, 2013: East and South Asia, San José State University Catalog, http://info.sjsu.edu/web-dbgen/catalog/ courses/GEOG160.html (19. 4. 2014).

University of South Florida, 2013: Geography of Asia, Undergraduate study: Information for Geography Majors, http://hennarot. forest.usf.edu/main/depts/geosci/ug/geography/ (19. 4. 2014).

Georgia State University, Department of Geoscience, 2013: Geography of East Asia, Graduate Geography Courses, http://geosciences. gsu.edu/1638.html (19. 4. 2014).

University of Wisconsin-Madison: Department of Geography, 2014: Human Geography of Southeast Asia, http://www.geography wisc.edu/courses/syllabi/358_spring.pdf (19.4.2014).

University of British Columbia, Department of Geography, 2013: Geography of Southeast Asia, Courses in Geography, http://www. geog.ubc.ca/undergraduate/courses_all.html (19.4.2014).

University of Western Ontario, Department of Geography, 2013: Geography of East and Southeast Asia, http://geography.uwo.ca/ undergrad/courses/2040A.pdf (19. 4. 2014.).

National University of Singapore, Department of Geography Southeast Asia, 2013: Undergraduate Modules, http://www.fas.nus.edu. sg/geog/undergrads/undergrad_modules.html\#tab2-tab (19.4. 2014.).

Sveučilište u Zagrebu, Prirodoslovno-matematički fakultet, Geografski odsjek, 2013: Geografija Istočne Azije, http://www.pmf.unizg. $\mathrm{hr} / \mathrm{geog} / \mathrm{predmet} / \mathrm{gia}(19.4 .2014)$

\section{Study books/Studijske knjige}

Lovrenčak, F., n. d.: Študijska skripta pri predmetu Regionalna geografjja Azije, Filozofska fakulteta, Univerza v Ljubljani, Ljubljana.

Vintar Mally, K., 2010: Geografija Azije: Študijsko gradivo, Univerza v Ljubljani, Filozofska fakulteta, Oddelek za geografijo, Ljubljana

Vovk Korže, A., 2000: Študijsko gradivo za regionalno geografijo Azije, Filozofska fakulteta, Oddelek za geografijo, Maribor.
Educational Approches in Regional

Geography: A Case Study of Southeast

Asia

Obrazovni pristupi u regionalnoj geografiji: jugoistočna

Azija - studija slučaja

\section{Appendices}

Prilozi 
HRVATSKI

GEOGRAFSKI

GLASNIK

78/2,101-120 (2016.)

\section{Textbooks/Udžbenici}

Cole, J., 1996: Geography of the world's major regions: textbook, Routledge, London, New York.

Harm J. de Blij in Muller, J., 1997: Geography: Realms, Regions and Concepts: textbook, J. Wiley \& Sons, New York.

Hobbs, J. J., Salter, C. L., 2000: Essentials of World Regional Geography: textbook. Brooks/Cole Publishing, UK.

Kolenc-Kolnik, K., Otič, M., Vovk Korže, A., 2002: Sodobni svet: Geografija za 7. razred osnovne šole: učbenik., Modrijan, Ljubljana.

Pulsipher, L. M., Pulsipher, A. A., 2002: World Regional Geography: Global Patterns, Local Lives: textbook, W.H. Freeman and Company, New York

Račič, J., Tomčič, Ž., 2005: GEOGRAFIJA 7, učbenik za geografijo v 7. razredu osnovne šole, Mladinska knjiga, Ljubljana.

Rigg, J., 1991: Southeast Asia: A Region in Transition: textbook, Routledge, London, New York.

Rowntree, L., Lewis, M., Price, M., Wyckoff, W., 2012: Diversity Amid Globalization: World Regions, Environment, Development: textbook, Pearson Prentice Hall, Boston.

Senegačnik, J., Drobnjak, B., 2000: Spoznavamo Evropo in Azijo: Geografija za 7. razred devetletne osnovne šole: učbenik, Modrijan, Ljubljana.

Senegačnik, J., 2009: Geografja Evrope in Azije: Učbenik za 7. razred osnovne šole, Modrijan, Ljubljana.

Verdev, H., 2010: Raziskujem stari svet 7: učbenik za geografijo v 7. razredu osnovne šole, Založba Rokus Klett, Ljubljana, E-gradivo http://www.irokus.si/index.do;jsessionid=fd37157f8d0789acc1a2a32f5129

\section{E-materials/E-materijali}

Annenberg Learner, n. d.: The Power of Place: Geography for the 21st Century, http://www.learner.org/series/powerofplace/page13. html (23. 3. 2014).

Facka, n. d.: Azija: Največja svetovna celina, http://www.facka.si/gradiva/geo/azija/ (23. 3. 2014.).

National Geographic, n. d.: Glencoe World Geography and Cultures, http://glencoe.mcgraw-hill.com/sites/0078745292/student view0/unit10/ (23.3.2014)

Svarog, n. d.: Jugovzhodna Azija, http://mss.svarog.si/geografija/index.php?page_id=11023 (23. 3. 2014.).

\section{Books/Knjige}

Berglee, R., 2012: World Regional Geography: People, Places and Globalization, Flat World Knowledge, http://www.saylor.org/site/textbooks/World\%20Regional\%20Geography.pdf

Chapman, G. P., Baker, K. M., 1992: The Changing Geography of Asia, Routledge, London, New York.

Frohlich H. L., Schreinemachers, P., 2013: Sustainable Land Use and Rural Development in Southeast Asia: Innovations and Policies for Mountainous Areas. http://link.springer.com/book/10.1007\%2F978-3-642-33377-4 (23. 3. 2014)

Gupta, A., 2005: The Physical Geography of Southeast Asia, Oxford University Press, Oxford.

Heidhues, F., Herrmann, L., Neef, A., 2007: Sustainable Land Use in Mountainous Regions of Southeast Asia, Springer, Berlin, Heidelberg. Hill, R., 2002: Southeast Asia: People, Land and Economy, Allen \& Unwin, Sydney.

Koh, L., Kettle, C., 2013: Biodiversity state and trends in Southeast Asia. http://www.dbs.nus.edu.sg/lab/evol-ecol/documents/Koh_etal_ Ency_Biod_2013.pdf (23.3.2014)

Rigg, J., 2003: Southeast Asia: The Human Landscape of Modernization and Development, Routledge, New York, London.

Weightman, B. A., 2002: Dragons and tigers: a geography of South, East, and Southeast Asia, John Wiley, New York.

Authors

Autori
Ana Vovk Korže ana.vovk@um.si Full Professor, University of Maribor, Department of Geography, Koroška cesta 160, 2000 Maribor, Slovenia

Sandra Špoljar $\quad$ spoljar.sandra@gmail.com

Teacher of Geography and Sociology, Primary school Louis Adamič, Tovarniška cesta 14, 1290 Grosuplje, Slovenia 